\section{The Relationship between Spiritual Intelligence and Work Satisfaction among Leaders and Employees}

\author{
Maja Koražija \\ PhD Student at the University of Maribor, Faculty of Economics and \\ Business, Slovenia \\ maja.korazija@gmail.com \\ Simona Šarotar Žižek \\ University of Maribor, Faculty of Economics and Business, Slovenia \\ simona.sarotar-zizek@um.si \\ Damijan Mumel \\ University of Maribor, Faculty of Economics and Business, Slovenia \\ damijan.mumel@um.si
}

\begin{abstract}
This study aims to investigate the relationship between spiritual intelligence and work satisfaction among both leaders and employees. Most studies in this area have focused on researching the relationship between employees' spiritual intelligence and work satisfaction, so we also researched the relationship between leaders' spiritual intelligence and work satisfaction. Our leading thesis was that leaders and employees with a higher level of spiritual intelligence have a higher level of work satisfaction. In our study, we found no significant relationship between spiritual intelligence and work satisfaction for leaders, but we found a significant positive relationship between spiritual intelligence and workplace satisfaction for employees.
\end{abstract}

Keywords: spiritual intelligence, work satisfaction, leaders, employees

\section{Introduction}

The majority of the developed world is in a post-materialistic period, in which not only people's basic needs but also their needs in the workplace are changing. Because jobs have largely transformed from routine to more creative positions in which the main components are the abilities and competence of the human mind, higher-order needs have emerged. To satisfy these needs, leadership must be based not on profits, but on values (Fry, 2003). Such a leader has not only a high level of cognitive intelligence, but also a high degree of emotional and spiritual intelligence. Cognitive and emotional intelligence constructs are fairly well known; meanwhile, the theory of spiritual intelligence is in the early stages of development. In one of the earliest definitions, Zohar and Marshal (2000) defined spiritual intelligence as

what we use to develop our longing and capacity for meaning, vision, and value. It allows us to dream and to strive. It underlies the things we believe in and the role our beliefs and values play in the actions that we take and the way we shape our lives. (p. 3)
ORIGINAL SCIENTIFIC PAPER

RECEIVED: JUNE 2015

REVISED: JANUARY 2016

ACCEPTED: JANUARY 2016

DOI: 10.1515/ngoe-2016-0012

UDK: 005.32:331.101.32

JEL: M54

Citation: Koražija, M., Šarotar Žižek, S. \& Mumel, D. (2016). The Relationship between Spiritual Intelligence and Work Satisfaction among Leaders and Employees. Naše gospodarstvo/Our Economy, 62(2), 51-60. DOI: 10.1515/ ngoe-2016-0012

\section{NG OE}

NAŠE GOSPODARSTVO OUR ECONOMY

Vol. 62 No. 2016

pp. $51-60$ 
To create a complete picture of human intelligence, we need to understand all of the various types of intelligence. In his theory of multiple intelligences, Gardner (1999) included nine different types of intelligence (natural, musical, logical, existential, interpersonal, physical, linguistic, emotional, and spatial). Spiritual intelligence is integrated into the model of multiple intelligences as a concept of existential intelligence, which is concerned with the "ultimate issues" of life (Gardner, 1999). Halama and Strizenec (2004) subsequently concluded that the existential and spiritual intelligences are "related and overlapping constructs with some common as well as unrelated aspects” (p. 15).

Working without purpose and meaning leaves people unsatisfied and causes organizations to struggle to create an identity in the market and contribute to the communities they serve (Covey, 1990; Deming, 1981). The results of a study among teachers in master's (MA) and bachelor's (BA) programs conducted by Yahyazadeh-Jeloudar and Lotli-Goodarzi (2012) showed a significant relationship between work satisfaction and spiritual intelligence.

Both leaders and employees are equally important group entities for a successful organization. Several research papers have examined the relationship between employees' spiritual intelligence and work satisfaction (Nodehi \& Nehardani, 2013; Sadeghi, Zamani, \& Mamasani, 2015; Yahyazadeh-Jeloudar \& Lotli-Goodarzi, 2012), but due to a lack of studies among leaders, the main objective of the present study is to investigate the relationship between spiritual intelligence and the work satisfaction of both leaders and employees. The conceptual framework presented in this paper will help provide a modest contribution to the literature on this phenomenon, especially on the empirical fronts.

\section{Definitions of Key Concepts}

\subsection{Spiritual intelligence}

It is important to realize how we perceive the environment, how we understand the background and meaning of events, and that we have the ability to imagine new steps and open up new possibilities. "Intelligence is the strongest predictor of our cognitive achievements, as well as our school and academic performance” (Musek \& Maravič, 2004, p. 5).

Gardner (1999) first introduced the theory of multiple intelligences, which posits that intelligence is more than a single property of the human mind. He did not include the concept of spiritual intelligence in his theory; instead, he used the concept of existential intelligence as viable. Emmons (2000) took it a step further in presenting the evidence that spirituality meets the criteria for intelligence. He identified five components of spiritual intelligence: the capacity for transcendence; the ability to enter into heightened spiritual states of consciousness; the ability to invest everyday activities, events, and relationships with a sense of the sacred; the ability to utilize spiritual resources to solve problems in living; and the capacity to engage in virtuous behavior (to show forgiveness, to express gratitude, to be humble, and to display compassion).

With a high level of spiritual intelligence, we can use our spirituality to bring meaning, importance, and general enrichment to our lives. This helps us achieve personal integrity, determine the purpose of our lives, and stay on the right path (Zohar \& Marshall, 2000). Because of spiritual intelligence, we are integrated-rationally, emotionally, and spiritually-creatures/individuals (Zohar \& Marshall, 2000). Ideally, these three (cognitive, emotional, and spiritual) basic human intelligences work together and support each other, but each can operate independently in a certain area.

Emotional intelligence enables us to assess the situation we are in and how we can properly find ourselves in it. On the other hand, spiritual intelligence allows us to ask ourselves whether we want to be in this particular situation or whether we would prefer to change the situation and create another, more appropriate one. This means changing and moving our limitations, which allows us to self-direct our position. Spiritual intelligence links all of our intelligences by allowing us to recognize what is truly important (Schwartz, 1995; Vaughan, 2002).

Wolman (2001) defined spiritual intelligence as "the human capacity to ask ultimate questions about the meaning of life and to experience simultaneously the seamless connection between each of us and the world in which we live" (p. 83). Wolman (2001) identified seven factors that make up human spiritual experience and behavior: divinity, mindfulness, intellectuality, community, extrasensory perception, childhood spirituality, and trauma. A clear and widely accepted definition suggested by Vaughan (2002) describes spiritual intelligence as "a capacity for a deep understanding of existential questions and insight into multiple levels of consciousness” (p. 19). King (2008) proposed four core components to comprise spiritual intelligence: critical existential thinking, personal meaning production, transcendental awareness, and conscious state expansion. Ronel (2008) continued the idea, asserting that spiritual intelligence is a key capability that connects us to something bigger than ourselves and is reflected not only in the values, but also in the motivation, intentions, emotions, 
and personality structure of an individual. He described spiritual intelligence as the ability to understand, emote, evaluate, create, and administrate. He understood spiritual intelligence to be an ability that goes beyond the desires and motives of individuals; it is not present to serve their selfish interests, but to lead them toward spiritual meaning.

Wigglesworth (2012) defined spiritual intelligence as "the ability to behave with wisdom and compassion, while maintaining inner and outer peace, regardless of the situation" (p. 7). She asserted that we can develop the ability to hear the voice of our higher self and our ego and then be guided by deep wisdom and compassion.

\subsubsection{Spiritually intelligent leaders}

Spiritually intelligent leaders represent more than just a new kind of ideal leadership; they represent a shift in the paradigm of leadership. This shift affects employees and managers as they transform their standards of success. No matter what kind of work we perform, it can always be done with heart and soul (Fairholm, 2000). The new paradigm of spiritual leadership focuses on vision, empowerment, risk, creativity, harmony, trust, honesty, and compassion. The terms that accompany this new paradigm are spiritual leadership (Wolf, 2004), moral conduct (Thompson, 2004), authentic leadership (Beagrie, 2005), and ethical conduct (Marques, 2006).

Leaders need to feel responsible in all situations and be respected by others (i.e., employees). Decision-making must take place through the prism of empathy (Šarotar Žižek, 2008). Leaders who exhibit grace and values such as joy, beauty, optimism, and confidence are more likely to inspire their employees. Kouzes and Posner (as cited in Amram, 2009) stressed the importance of self-orientation-which refers to being circumspect, possessing clarifying values, being honest, and living in conjunction with these principles_and setting criteria for employees. These are some of the essential qualities of spiritually intelligent leadership, which every good leader should possess and learn to emphasize.

\subsubsection{Spiritually intelligent employees}

Spiritually intelligent leaders are not the only ones who are important to the overall organizational structure; equally important are employees. Spiritual intelligence and profitability are not mutually exclusive; in fact, integrating ethics and spiritual values into the workplace can lead to higher productivity and profitability, happier employees, and more honest relationships with customers and can help build the organization's reputation (Marques, 2006). Spiritually intelligent employees are more consistent with themselves, happier, and more deeply integrated and harmonious (George, 2006).

Despite the fact that spiritually intelligent employees are of great value for organization, George (2006) stressed that no universal prescription exists for how to seek and find spiritual intelligence. Each individual has to find it for him-/herself, and only he/she knows how to obtain it. There is also a universal question of how to find an external power and vitality and give it meaning and significance for all external events. Such challenges are much more present for employees during difficult times, when values are not the priority for their leaders and employees are seen only as tools for gaining profits.

\subsubsection{Spiritually intelligent organization}

Fry (2003) argued that "organizational environments in the 21st century are chaotic and require rapid response from highly committed, productive, intrinsically motivated learning organizations” (p. 717). In order for organizations to meet the great challenges they face successfully, they have to make a radical shift and transformation to a new business model-a spirituality-based organization.

Spiritual intelligence provides employees a sense of interconnectedness and community. Workplaces are places where people spend most of their lives, develop friendships, create value, and make their most meaningful contributions to society (Fairholm, 2000). Furthermore, companies that engage not just the minds, but also the hearts and emotions of their employees will be more profitable. In other words, an organization that earnestly treats its employees and leaders as part of its community and emotionally engages them in the organization's purposes, which makes all the difference in the world and will attract a higher level of leaders and employees' motivation and loyalty, ultimately leading to higher organizational performance (Brown, 1999).

\subsection{Work satisfaction}

The term "work satisfaction" is used in several different sciences, including (organizational) psychology, sociology, and management. A number of experts believe that the trends of work satisfaction influence the functioning of the labor market and labor productivity, work effort, work absenteeism, and staff resignations (European Foundation for the Improvement of Living and Working Conditions, 2007). 
Organizations have a major impact on the people who work in them. One of these effects is reflected in individuals' relationship with (Brayfield \& Rothe, 1951) and about their workplace (Spector, 1997, as cited in European Foundation for the Improvement of Living and Working Conditions, 2007). Evans's (1997) definition connects work satisfaction to the needs associated with the workplace and an individual's perception of the degree of satisfaction.

An alternative to the traditional view of work satisfaction was offered by Sousa-Paz and Sousa-Poza (2000) based on the assumption that there are basic and universal human needs. If an individual's needs are met in their current situation, that person can be considered happy. Due to the fact that people spend a major part of their life in the workplace, it is important that they are "happy in the workplace" (Nguyen, Taylor, \& Bradley, 2003, p. 133). "More satisfied employees are more efficient and effective at their work. For this reason an organization can be truly effective and successful only if inside of that organization work a majority of satisfied individuals” (Regent, 2013).

\section{Research Question and Hypothesis Development}

Personal characteristics that can be developed through a higher level of spiritual intelligence and those needed for higher work satisfaction are very similar and, at some point, even overlap (Tischler, Biberman, \& McKeage, 2002; Zembylas \& Papanastasious, 2004). It is important to realize that a person who is happy in the workplace will consequently experience the world outside the work environment as less stressful. Generally speaking, such a person has a greater sense of well-being (Marques, 2006). Spiritual intelligence can be considered a method for improving the well-being of management executives as well as organizational well-being (Subramaniam \& Panchanatham, 2014).

People with a higher level of spirituality are happier and more satisfied with life than people with a lower level of spirituality (Cohen, 2002; Perrone, Webb, Wright, Jackson, \& Ksiazak, 2006). Spirituality can have a tremendous impact on an individual's life, such as by creating a better balance of work, family, and life satisfaction (Perrone et al., 2006).

Some studies have demonstrated a significant positive relationship between employees' spiritual intelligence and work satisfaction (Nodehi \& Nehardani, 2013; Sadeghi et al., 2015; Yahyazadeh-Jeloudar \& Lotli-Goodarzi, 2012). In contrast, Rastgar, Davoudi, Oraji, and Abbasian (2012) investigated the relationship between employees' spiritual intelligence and work satisfaction, but found no significance.

Given the contradictory results we found in the investigation of the relationship between employees' spiritual intelligence and work satisfaction, and because it makes sense to investigate the same relationship in leaders, we decided to conduct a study to answer the following research question: Is the spiritual intelligence of leaders and employees positively correlated with their level of work satisfaction? Based on the reviewed literature and our research question, we designed the thesis of this research: Leaders and employees with a higher level of spiritual intelligence also have a higher level of work satisfaction. Thus, we formulated the following two hypotheses:

H1: Leaders with a higher level of spiritual intelligence have a higher level of work satisfaction.

H2: Employees with a higher level of spiritual intelligence have a higher level of work satisfaction.

\section{Method}

\subsection{Instruments}

To measure spiritual intelligence we used the Integrated Spiritual Intelligence Scale (ISIS) (Amram \& Dryer, 2007). The reliability of the ISIS was high (i.e., Cronbach's alpha $=0.97$ ). This self-reporting instrument provides an overall measure of spiritual intelligence as well as scores for five dimensions of spiritual intelligence: consciousness, grace, meaning, transcendence, and truth (Amram \& Dryer, 2007). The instrument comprises 45 items and uses a 5-point summative response scale. Positively worded items are scored from 1 to 5 while negatively worded items are scored conversely. Overall scores for an individual can range from a minimum of 45 to a maximum of 225. A low score indicates a lower level of spiritual intelligence whereas a high score indicates a higher level of spiritual intelligence. Overall, spiritual intelligence measured based on the sum of the ISIS dimensions scores was previously used by Shabani, Hassan, Ahmad, and Baba (2010) and Yahyazadeh-Jeloudar and Lotfi-Goodarzi (2012).

To measure the work satisfaction, we used the Job Descriptive Index (JDI) (Smith, Kendall, \& Hulin, 1969), which is one of the most widely used measures of work satisfaction (Landy, Shankster, \& Kohler, 1994). We used a version that was already translated into the Slovenian language and validated in Slovenia (Sabadin, 1978). There are five dimensions of JDI: work, coworkers, supervision, pay, and promotion 
(Smith et al., 1969). The version we used is composed of 106 items and uses a 3-point summative response scale. Positively worded items are scored with 3,1 , and 0 points whereas negatively worded items are scored conversely. Overall, scores for an individual can range from a minimum of 0 to a maximum of 318; a low score indicates a lower level of work satisfaction whereas a high score indicates a higher level of work satisfaction. Overall, work satisfaction measured using the sum of the JDI dimensions scores was previously used by Crossman and Abou-Zaki (2003) and Shaikh, Bhutto and Maitlo (2012).

When analyzing the reliability of the instruments used in our study, we calculated Cronbach's alpha coefficients. The Cronbach's alpha for ISIS was 0.810 and for JDI was 0.946 , which indicates a high level of reliability according to George and Mallery (2003).

\subsection{Data collection procedure and sample profile}

Data were collected in one of the largest metal manufacturing companies in Slovenia, which employs 1,150 people. Surveys were sent to a random sample of 100 leaders and 100 employees (a total of 200 questionnaires). We used a drop-off/pick-up method with printed copies of the questionnaire. The response rates were 37\% (37 respondents) for leaders and 75\% (75 respondents) for employees, resulting in a total of 112 respondents. The overall response rate was $56 \%$. Table 1 summarizes the sample profile.

\section{Results}

\subsection{Spiritual intelligence and work satisfaction of leaders and employees}

The means (M) and standard deviations (SD) of leaders' and employees' work satisfaction and spiritual intelligence are presented in Table 2.

We tested normality using the Shapiro-Wilk test. Given that $W=0.957$ and $p=0.167$ for the leaders' spiritual intelligence, $W=0.976$ and $p=0.160$ for employees' spiritual intelligence, $W=0.971$ and $p=0.424$ for leaders' work satisfaction, and $W=0.974$ and $p=0.130$ for employees' work satisfaction $(p>0.05)$, we concluded that both variables for both independent samples were normally distributed. Therefore, the assumption of normality was met. In addition, our data satisfied the assumption of homoscedasticity of variances via Levene’s F test: $\mathrm{F}(110)=2, p=0,160$.

An independent-samples $t$-test was conducted to compare the differences between the means of leaders' and employees' spiritual intelligence and between the means of leaders' and employees' work satisfaction. Leaders $(\mathrm{M}=154.5$, $\mathrm{SD}=12.04)$ showed significantly higher scores than employees $(\mathrm{M}=147.0, \mathrm{SD}=14.56)$ on the spiritual intelligence scale ( $p<0.05$ ), but no significant difference existed between leaders $(\mathrm{M}=184.5, \mathrm{SD}=49.65)$ and employees $(\mathrm{M}=168.5$, $\mathrm{SD}=47.40$ ) in terms of work satisfaction (Table 2 ).

Table 1. Sample Profile

\begin{tabular}{|c|c|c|c|c|c|c|c|}
\hline \multirow{2}{*}{\multicolumn{2}{|c|}{ Frequency }} & \multicolumn{2}{|c|}{ Leaders } & \multicolumn{2}{|c|}{ Employees } & \multicolumn{2}{|c|}{ Total } \\
\hline & & Proportion & Frequency & Proportion & Frequency & Proportion & \\
\hline \multirow{2}{*}{ Gender } & Female & 16 & 0.43 & 33 & 0.44 & 49 & 0.44 \\
\hline & Male & 21 & 0.57 & 42 & 0.56 & 63 & 0.56 \\
\hline \multirow{4}{*}{ Age } & Below 30 & 3 & 0.8 & 18 & 0.24 & 21 & 0.19 \\
\hline & $31-40$ & 18 & 0.49 & 23 & 0.31 & 41 & 0.37 \\
\hline & $41-50$ & 12 & 0.32 & 23 & 0.31 & 35 & 0.30 \\
\hline & Above 50 & 4 & 0.11 & 11 & 0.14 & 15 & 0.14 \\
\hline \multirow{4}{*}{ Education } & $\begin{array}{c}\text { Short-cycle tertiary } \\
\text { education }\end{array}$ & 5 & 0.14 & 42 & 0.56 & 47 & 0.42 \\
\hline & $\begin{array}{l}\text { Bachelor or } \\
\text { equivalent }\end{array}$ & 9 & 0.24 & 11 & 0.15 & 20 & 0.18 \\
\hline & $\begin{array}{l}\text { Master or } \\
\text { equivalent }\end{array}$ & 17 & 0.46 & 21 & 0.28 & 38 & 0.34 \\
\hline & $\begin{array}{c}\text { Doctorate or } \\
\text { equivalent }\end{array}$ & 6 & 0.16 & 1 & 0.10 & 7 & 0.60 \\
\hline \multirow{4}{*}{$\begin{array}{l}\text { Years of work } \\
\text { experience }\end{array}$} & Below 10 & 6 & 0.16 & 24 & 0.32 & 30 & 0.27 \\
\hline & $11-20$ & 18 & 0.49 & 26 & 0.35 & 44 & 0.39 \\
\hline & $21-30$ & 10 & 0.27 & 16 & 0.21 & 26 & 0.23 \\
\hline & Above 30 & 3 & 0.8 & 9 & 0.12 & 12 & 0.11 \\
\hline
\end{tabular}


Table 2. Means, Standard Deviations, and t-tests of Variables Used in the Study for Leaders and Employees

\begin{tabular}{cccccccccccccc} 
& \multicolumn{1}{c}{ Leaders } & \multicolumn{1}{c}{ Employees } & \multicolumn{1}{c}{ Total } & & $t$-test \\
\hline Scale & $\mathrm{N}$ & $\mathrm{M}$ & $\mathrm{SD}$ & $\mathrm{N}$ & $\mathrm{M}$ & $\mathrm{SD}$ & $\mathrm{N}$ & $\mathrm{M}$ & $\mathrm{SD}$ & $t$ & $\mathrm{df}$ & $p$ \\
\hline $\begin{array}{c}\text { Overall } \\
\text { spiritual } \\
\text { intelligence }\end{array}$ & 37 & 154.5 & 12.04 & 75 & 147.0 & 14.56 & 112 & 149.5 & 14.17 & 2.69 & 110 & .008 \\
\hline $\begin{array}{c}\text { Overall work } \\
\text { satisfaction }\end{array}$ & 37 & 184.5 & 49.65 & 75 & 168.5 & 47.40 & 112 & 173.8 & 48.53 & 2.87 & 110 & .101 \\
\hline
\end{tabular}

\subsection{Hypothesis testing}

Hypothesis H1 predicts that leaders with a higher level of spiritual intelligence will have a higher level of work satisfaction. A Pearson's correlation was applied to determine the relationship between two variables. No statistically significant correlation existed between spiritual intelligence and work satisfaction for leaders ( $p>0.05$; see Table 3 ). Therefore, leaders' spiritual intelligence and work satisfaction were not found to be significantly correlated, and hypothesis H1 was not accepted.

Table 3. Correlation between Spiritual Intelligence and Work Satisfaction of Leaders and Employees

\begin{tabular}{ccc} 
& Leaders & Employees \\
\hline Pearson Correlation & 0.090 & 0.289 \\
\hline Sig. (2-tailed) & 0.596 & $\mathbf{0 . 0 1 2}$ \\
\hline $\mathrm{N}$ & 37 & 75 \\
\hline
\end{tabular}

Hypothesis H2 predicts that employees with a higher level of spiritual intelligence will have a higher level of work satisfaction, so we examined the relationship between spiritual intelligence and work satisfaction among employees. The correlation between employees' work satisfaction and spiritual intelligence showed that they are significantly positively correlated $(p<0.05)$, so hypothesis H2 was accepted.

\section{Discussion and Implications}

Few studies have been conducted on spirituality as spiritual intelligence has only been recently recognized. Spiritual intelligence is currently expanding as a researched phenomenon, although research is still in its early stages. In Slovenia, only a few studies by Musek (2008) and Šarotar Žižek (2008, 2012) have explored the field of spiritual intelligence.

Most researchers initially focused only on the exploration of the separate constructs: leaders' spiritual intelligence and employees' work satisfaction. They subsequently investigated the relationship, but only of employees' spiritual intelligence and work satisfaction. They missed the relationship between leaders' spiritual intelligence and work satisfaction. For this reason, we expanded the scope of our research to explore the relationship between leaders' spiritual intelligence and work satisfaction.

\subsection{Conclusions}

The results of our research showed a significant positive relationship between employees' spiritual intelligence and work satisfaction, which is inconsistent with some of the previous literature that found employees' spiritual intelligence and work satisfaction are not significantly correlated (Rastgar et al., 2012). The differences between Rastgar et al.'s (2012) findings and our findings can be explained by the different methodological approaches applied. Rastgar et al. used other measurement instruments and statistical methods. To measure spiritual intelligence, they used the Psycho Matrix Spirituality Inventory, whereas we used ISIS. To measure work satisfaction, they used the Index of Work Satisfaction whereas we used JDI. They tested their hypothesis using structural equation modeling (SEM); we used with Pearson's correlation coefficient. However, our results are consistent with the findings of Yahyazadeh-Jeloudar and Lotli-Goodarzi (2012), Nodehi and Nehardani (2013), and Sadeghi et al. (2015), who also found a significant relationship between employees' spiritual intelligence and work satisfaction.

For leaders, we found no significant relationship between spiritual intelligence and work satisfaction. We could not compare this result with other studies as we found no previous relevant research. Comparing the spiritual intelligence of leaders and employees, we found that the level of leaders' self-reported spiritual intelligence is significantly higher than that of employees. Although leaders' self-reported level of work satisfaction was higher than that of employees, no significant difference emerged.

\subsection{Managerial implications}

Zohar and Marshall (2004) argued that spiritual intelligence should be grown and developed with training. This 
is consistent with Wigglesworth's (2012) study, which found that mature leadership requires spiritual intelligence development. The development of employees' spiritual intelligence level will enhance their abilities and increase their level of work satisfaction.

The findings of our study suggest that human resource managers should formulate strategies for developing and increasing employees' spiritual intelligence, because we found a significant positive relationship between employees' spiritual intelligence and work satisfaction. These strategies could help increase employees' work satisfaction, which can result in higher productivity, organizational commitment, and organizational efficiency as well as loyalty, presentism, and less absenteeism and fluctuation. Therefore, the concepts of spiritual intelligence and work satisfaction need to be understood in greater detail by human resource managers and leaders.

Human resource managers should assess the spiritual intelligence of their job applicants in order to recruit the best candidates. They should do the same throughout employees' careers so they can adjust training and education to their spiritual needs. The development of spiritual intelligence could be a valuable part of an organization's development strategy as a way to create similar objectives and goals among employees in relation to the objectives and goals of the entire organization.

\section{Limitations and Further Research}

Our research has some limitations. We gathered information in only one organization, so we cannot generalize the results of our research to other organizations. Our study only represents the situation in that particular organization. In addition, self-reporting can vary in terms of reliability and validity, although it is generally considered a useful technique to measure work satisfaction and spiritual intelligence. Future research should use multiple assessments of leaders' and employees' spiritual intelligence. In addition to self-assessments, leaders can assess employees’ spiritual intelligence and vice versa.

The spiritual intelligence construct is far from achieving consensus across the scientific community. New definitions and findings on spiritual intelligence (Mahajan, 2015) have appeared in different segments and in general, which opens new dimensions for understanding spiritual intelligence.

We only used an overall measure of work satisfaction for the purposes of this article. In terms of practice, by measuring all five dimensions of work satisfaction, organizations and their managers can obtain a complete view of employees' specific work satisfaction with work itself, pay, opportunity for promotion, supervision, and coworkers.

We found a significant relationship between employees' spiritual intelligence and workplace, but not with leaders. Future studies are needed to extend these findings using more diverse predictors and criteria.

Spiritual intelligence is a good predictor of general well-being (Musek, 2008), subjective well-being (Šarotar Žižek, Treven, \& Mulej, 2011), and health (Perrone et al. 2006; Sousa-Poza \& Sousa-Poza, 2000). Because all these studies were conducted separately for each pair of constructs, it could be beneficial if more concepts were analyzed in one comprehensive study.

\section{References}

1. Amram, Y. (2009). The contribution of emotional and spiritual intelligences to effective business leadership. Palo Alto, CA: Institute of Transpersonal Psychology.

2. Amram, Yosi \& Dryer, Christopher. (2007). The Development and Preliminary Validation of the Integrated Spiritual Intelligence Scale (ISIS). Palo Alto, CA: Institute of Transpersonal Psychology Working Paper. Available on http://www.geocities.com/isisfindings/

3. Beagrie, R. (1999). Why the future belongs to value added companies. The Journal for Quality \& Participation, 22(1), 884-895. Retrieved from http://dx.doi.org/10.1108/02621710610692089

4. Brayfield, A. H., \& Rothe, H.F.(1951). An index of job satisfaction.Journal of Applied Psychology, 35(5), 307-311. Retrieved from http:// psycnet.apa.org/doi/10.1037/h0055617

5. Brown, E. (1999). America's most admired companies. Fortune, 1(3), 68-73.

6. Cohen, A. B. (2002). The importance of spirituality in well-being for Jews and Christians. Journal of Happiness Studies, 3, $287-310$. Retrieved from http://dx.doi.org/10.1023/A:1020656823365

7. Covey, S. R. (1990). Principle-centered leadership. New York: Fireside.

8. Crossman, A., \& Abou-Zaki, B. (2003). Job satisfaction and employee performance of Lebanese banking staff. Journal of Managerial Psychology, 18(4), 368-376. Retrieved from http://dx.doi.org/10.1108/02683940310473118 
9. Deming, W. E. (1981). Improvement of quality and productivity through action by management. National Productivity Review, 1(1), 12-22. Retrieved from http://dx.doi.org/10.1002/npr.4040010105

10. Emmons, R.A. (2000). Is spirituality an intelligence? The International Journal for the Psychology of Religion, 10, 27-34. Retrieved from http://dx.doi.org/10.1207/S15327582IJPR1001_2

11. European Foundation for the Improvement of Living and Working Conditions. (2007). Measuring job satisfaction in surveys-comparative analytical report. Retrieved from http://www.eurofound.europa.eu/sites/default/files/ef_files/ewco/reports/TN0608TR01/ TN0608TR01.pdf

12. Evans, L. (1997). Understanding teacher morale and job satisfaction. Teaching and Teacher Education, 13(8), 831-245. Retrieved from http://dx.doi.org/10.1016/S0742-051X(97)00027-9

13. Fairholm, G. W. (2000). Capturing the heart of leadership (spirituality and community in the new American workplace). Westpoint, CT, London: Praeger.

14. Fry, L. W. (2003). Toward a theory of spiritual leadership. The Leadership Quarterly, 14(6), 693-727. Retrieved from http://dx.doi. org/10.1016/j.leaqua.2003.09.001

15. Gardner, H. (1999). Intelligence reframed: Multiple intelligences for the 21st century. New York: Basic Books.

16. George, D., \& Mallery, P. (2003). SPSS for Windows step by step: A simple guide and reference. Boston: Allyn \& Bacon.

17. George, M. (2006). Practical application of spiritual intelligence in the workplace. Emerald Group Publishing Limited, 3-5. Retrieved from http://dx.doi.org/10.1108/09670730610678181

18. Halama, P., \& Strizenec, M. (2004). Spiritual, existential or both? Theoretical considerations on the nature of higher intelligences. Studia Psychologica, 43, 239-253. Retrieved from http://katpsych.truni.sk/osobne/halama/Halama,\%20Str\%C3\%AD\%C5\%BEenec,\%202004.pdf

19. King, D. B. (2008). Rethinking claims of spiritual intelligence: A definition, model, \& measure (Unpublished master's thesis). Trent University, Peterborough.

20. Landy, F. J., Shankster, L. J., \& Kohler, S. S. (1994). Personnel selection and placement. Annual Review of Psychology, 45, $261-296$. Retrieved from http://org/doi/10.1037/0021-9010.83.1.3

21. Mahajan, R. (2015). Study of the relationship of research contribution and professional exposure of Indian agricultural scientists with their self-destructive intelligence syndrome and spiritual intelligence: Degree. India: Kumaun University.

22. Marques, J. F. (2006). The spiritual worker: An examination of the ripple effect that enhances quality of life in- and outside the work environment. Emerald Group Publishing Limited, 884-895. Retrieved from http://dx.doi.org/10.1108/02621710610692089

23. Mihalič, R. (2008). Povečajmo zadovoljstvo in pripadnost zaposlenih: praktični nasveti, metodologija, interni akt in model usposabljanja za upravljanje in merjenje zadovoljstva in pripadnosti zaposlenih, z ukrepi za večje zadovoljstvo pri delu in pripadnost organizaciji: priročnik. Škofja Loka: Mihalič in partner.

24. Musek, J. (2008). Duhovna inteligentnost: struktura in povezave. Anthropos, 3-4, 259-106. Retrieved from http://www.anthropos.si/ anthropos/2008/3_4/13_musek.pdf

25. Musek, J., \& Maravič, K. (2004). Vrednote in duhovna inteligentnost. Retrieved from http://www.dlib.si/stream/URN:NBN:SI:DOC-AV2TFKY5/a24f0214-d9d6-48dd-8d2f-acafa118c411/PDF

26. Nguyen, A. N., Taylor, Y., \& Bradley, S. (2003). Job autonomy and job satisfaction: Some new evidence (Working paper 045). Department of Economics: Lancaster University Management School. Retrieved from http://www.lancaster.ac.uk/staff/ecasb/papers/job\%20 autonomy\%20\%20job\%20satisfaction\%2030july03.pdf

27. Nodehi, H., \& Nehardani, H. (2013). Relation between spiritual intelligence and job satisfaction.Journal of Social Issues \& Humanities, 1(5), 67-72. Retrieved from http://www.journalsih.com/Research\%20Articles/Issue\%205/Relation\%20between\%20Spiritual\%20 Intelligence\%20and\%20Job\%20Satisfaction.pdf

28. Perrone, K. M., Webb, K. L., Wright. S. L., Jackson, V. Z., \& Ksiazak, Z. M. (2006). Relationship of spirituality to work and family roles and life satisfaction among gifted adults. Journal of Mental Health Counseling, 28(3), 253-268. Retrieved from http://dx.doi. org/10.17744/mehc.28.3.81a1dlhwelblce0v

29. Rastgar, A. A., Davoudi, S. M. M., Oraji, S., \& Abbasian, M. (2012). A study of the relationship between employees' spiritual intelligence and job satisfaction: A survey in Iran's banking industry. A Journal of Multidisciplinary Research, 1(2), 57-74. Retrieved from http://prj. co.in/setup/socialscience/paper9.pdf

30. Regent, P. (2013). Obremenjenost in zadovoljstvo pri delu v odnosu do izgorelosti učiteljev (doktorska disertacija). Ljubljana: Filozofska fakulteta Univerze v Ljubljani.

31. Ronel, N. (2008). The experience of spiritual intelligence. The Journal of Transpersonal Psychology, 40(1), 100-120. Retrieved from http://www.atpweb.org/jtparchive/trps-40-08-01-100.pdf

32. Sabadin, A. (1978). Kvantitativni vidik analize strukture dela (doktorska disertacija). Ljubljana: Filozofska fakulteta Univerze v Ljubljani.

33. Sadeghi, H., Zamani, A., \& Mamasani, A. N. (2015). Study the relationship between spiritual intelligence and emotion intelligence with the quality of work life Izeh principals. Journal of Scientific Research and Development, 2(1), 187-190. Retrieved from http://jsrad. org/wp-content/2015/Issue\%201,\%202015/33\%202015-2-1-187-190.pdf

34. Schwartz, T. (1995). What really matters: Searching for wisdom in America. New York: Bantam.

35. Shabani,J., Hassan, S.A.,Ahmad,A., \& Baba, M. (2010). Age as moderated influence on the link of spiritual and emotional intelligence with mental health in high school students. Journal of American Science, 6(11), 394-400. Retrieved from https://www.researchgate. 
net/profile/Aminah_Ahmad2/publication/265550153_Age_as_Moderated_Influence_on_the_Link_of_Spiritual_and_Emotional_In-

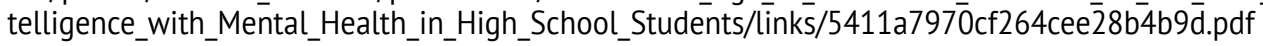

36. Shaikh, M. A., Bhutto, N. A., \& Maitlo, Q. (2012). Facets of job satisfaction and its association with performance. International Journal of Business and Social Science, 3(7), 322-326. Retrieved from http://ijbssnet.com/journals/Nol_3_No_7_April_2012/36.pdf

37. Smith, P. C., Kendall, L., \& Hulin, C. L. (1969). The measurement of satisfaction in work and retirement: A strategy for the study of attitudes. Chicago: Rand McNally.

38. Sousa-Poza, A. \& Sousa-Poza, A. A. 2000. Well-being at work: a cross-national analysis of the levelsand determinants of job satisfaction. Journal of Socio-Economics 29, 517-538 http://dx.doi.org/10.1016/S1053-5357(00)00085-8

39. Subramaniam, M., \& Panchanatham, N. (2014). Relationship between emotional intelligence, spiritual intelligence and wellbeing of management executives. Global Research Analysis, 3(3), 92-94

40. Šarotar Žižek, S. (2008). Pomen osebnega in osebnostnega razvoja človeških virov v (slovenskem) turizmu. Academica Turistica: Fakulteta za turistične študije, 3-4, 42-48. Retrieved from http://www.turistica.si/downloads/revija/AcademicaTuristica-Nr3-4-December2008.pdf

41. Šarotar Žižek, S. (2012). Vpliv psihičnega dobrega počutja na temelju zadostne in potrebne osebne celovitosti zaposlenega na uspešnost organizacije (doktorska disertacija). Maribor: Ekonomsko poslovna fakulteta Univerze v Mariboru.

42. Šarotar Žižek, S., Treven, S., \& Mulej, M. (2011). Povezava med psihičnim dobrim počutjem zaposlenih in duhovno inteligentnostjo kot dejavniki primerno celovitega menedžmenta. Moderna organizacija. Maribor: Fakulteta za organizacijske vede.

43. Thompson, L. (2004). Moral leadership in a postmodern world. Journal of Leadership and Organizational Studies, 11(1), 27-37. http:// dx.doi.org/10.1177/107179190401100105

44. Tischler, L., Biberman, J., \& McKeage, R. (2002). Linking emotional intelligence, spirituality and workplace performance: Definitions, models and ideas for research. Journal of Managerial Psychology, 17(3), 203-218. Retrieved from http://dx.doi. org/10.1108/02683940210423114

45. Vaughan, F. (2002). What is spiritual intelligence? Journal of Humanistic Psychology, 42(2), 16-33. http://dx.doi. org/10.1177/0022167802422003

46. Wigglesworth, C. (2012). SQ21: The 21 skills of spiritual intelligence. New York: Selected Books.

47. Wolf, E. (2004). Spiritual leadership: a new model. Healthcare Executive, 19(2), 22-25. Retrieved from http://www.ncbi.nlm.nih.gov/ pubmed/15017832

48. Wolman, R. N. (2001). Thinking with your soul: Spiritual intelligence and why it matters. New York: Harmony Books.

49. Yahyazadeh-Jeloudar, S., \& Lotli-Goodarzi, F. (2012). What is the relationship between spiritual intelligence and job satisfaction among MA and BA teachers? International Journal of Business and Social Science, 3(8), 299-303. Retrieved from http://ijbssnet.com/ journals/Nol_3_No_8_Special_Issue_April_2012/35.pdf

50. Zembylas, M., \& Papanastasiou, E. (2004). Job satisfaction among school teachers in Cyprus. Journal of Educational Administration, 42(3), 357-374. Retrieved from http://dx.doi.org/10.1108/09578230410534676

51. Zohar, D., \& Marshall, I. (2000). SQ-Spiritual intelligence, the ultimate intelligence. London: UL copy.

\section{Authors}

Maja Koražija is currently a Ph.D. student at the Faculty of Economics and Business at the University of Maribor. She earned her master's degree in human resource management, in which her main focus of study and research also lies. She actively participated in an international conference in India and presented her doctoral theme at Cambridge University. During most of her academic years, she has worked in the economic sector for Elektro Maribor and Steklarna Rogaška, where she worked on European funding projects.

Dr. Simona Šarotar Žižek is an assistant professor at the University of Maribor's Faculty of Economic and Business. She is the author and/or co-author of several articles published in various international and Slovenian journals and/or presented at scientific and expert conferences. She has prepared several scientific monographs and chapters in scientific and expert monographs. On several occasions she has been invited to present her papers at scientific and expert conferences. She is also active in preparing and implementing projects.

Dr. Damijan Mumel works as a professor of marketing at the University of Maribor, Faculty of Economics and Business. He is the head of the Marketing Institute and vice dean for research. His main areas of interest and lecturing are consumer behavior, research methodology, qualitative research, and communication. He has presented his work at international scientific conferences and published original scientific papers in domestic and foreign scientific journals. He is a member of the Slovenian Marketing Association and the Slovenian Psychologists' Association as well as the European Marketing Academy (EMAC). 


\section{Povezanost med duhovno inteligentnostjo in delovnim zadovoljstvom pri vodjih in zaposlenih}

\section{Izvleček}

Namen študije je raziskati odnos med duhovno inteligentnostjo in delovnim zadovoljstvom tako pri vodjih kot tudi pri zaposlenih. Raziskave $v$ preteklosti so se osredotočale le na raziskovanje povezanosti med duhovno inteligentnostjo in delovnim zadovoljstvom pri zaposlenih, zato smo $v$ našo raziskavo vključili tudi ugotavljanje povezanosti med duhovno inteligentnostjo in delovnim zadovoljstvom pri vodjih. Naša vodilna teza je bila, da vodje in zaposleni z višjo stopnjo duhovne inteligentnosti občutijo tudi več delovnega zadovoljstva. $\vee$ študiji smo ugotovili, da pri vodjih ni bilo statistično pomembne povezave med duhovno inteligentnostjo in delovnim zadovoljstvom, hkrati pa je bila ugotovljena statistično pomembna pozitivna povezava med duhovno inteligentnostjo in delovnim zadovoljstvom pri zaposlenih.

Ključne besede: duhovna inteligentnost, delovno zadovoljstvo, vodje, zaposleni 